\title{
PERBEDAAN PENGARUH PEMBERIAN TERAPI RELAKSASI AUTOGENIC TERHADAP PENURUNAN TINGKAT NYERI PADA PASIEN POST OPERASI SECTIO CAESARIA DI RUMAH SAKIT BUAH HATI CIPUTAT
}

\author{
${ }^{1}$ Riris Andriati, ${ }^{2}$ Yulia Heri Martina \\ 1,2 Program Studi S1 Keperawatan, STIKes Widya Dharma Husada Tangerang \\ Jalan Pajajaran No1, Pamulang Tangerang Selatan Banten \\ 1Email: ririsandriati@wdh.ac.id, ${ }^{2}$ Email: yuliaherim@gmail.com
}

\begin{abstract}
ABSTRAK
Pendahuluan: Sectio caesaria didefinisikan sebagai sebuah metode persalinan dimana janin lahir melalui insisi bedah yang dibuat di dinding perut (laparotomi) dan dinding rahim (histerotomi). Menurut WHO dalam penelitian Cut Sriyanti (2016), standar rata-rata sectio caesaria di sebuah negara sekitar 5-15\% per 1000 kelahiran didunia. Salah satu komplikasi sectio caesaria adalah nyeri pada daerah insisi. Strategi penatalaksanaan nonfarmakologi untuk meredakan nyeri salah satunya adalah terapi relaksasi autogenic. Terapi relaksasi autogenic adalah salah satu teknik relaksasi yang bersumber dari diri sendiri berupa kalimat pendek untuk bisa membuat pikiran tentram. Tujuan penelitian ini adalah mengidentifikasi perbedaan pengaruh pemberian terapi relaksasi autogenic terhadap penurunan tingkat nyeri pada pasien post operasi sectio caesaria di Rumah Sakit Buah Hati Ciputat. Metode: Desain penelitian yang digunakan dalam penelitian adalah Quasy Eksperimental dengan pendekatan The Randomized Pretest-Posttest With Control Group Design dengan jumlah sampel sebanyak 50 responden yang terdiri dari 25 responden sebagai kelompok intervensi dan 25 responden sebagai kelompok kontrol. Teknik pengambilan sampel menggunakan Non Probability Sampling berupa Purposive Sampling. Hasil: Rata-rata tingkat nyeri pada kelompok intervensi sesudah diberikan terapi relaksasi autogenic yaitu 2,88 dan pada kelompok kontrol yaitu 3,48. Hasil uji Mann-Whitney $U$, didapatkan $p$-value $0,024<\alpha(0,05)$. Kesimpulan: Perbedaan tingkat nyeri pada pasien post operasi sectio caesaria sesudah diberikan terapi relaksasi autogenic pada kelompok intervensi dan kelompok kontrol menunjukkan bahwa terdapat perbedaan pengaruh pemberian terapi relaksasi autogenic terhadap penurunan tingkat nyeri pada pasien post operasi sectio caesaria di Rumah Sakit Buah Hati Ciputat.

Kata Kunci : Terapi Relaksasi Autogenic, Tingkat Nyeri
\end{abstract}

\begin{abstract}
Introduction: Sectio Caesarea is defined as the birthing method where of a fetus is born through surgical incisions which made in the abdominal wall (laparotomy) and the uterine wall (hysterotomy). According to WHO in the research of Cut Sriyanti (2016), standars average of section caesarea in a country about 5-10 per 1000 births in the world. One of the complications of Sectio Caesarea is pain in the incision area. Non-pharmacologic pain management strategies for dealing with pain are autogenic relaxation therapy. Autogenic relaxation therapy is one of relaxation techniques where the source's is in the inside of our self in form a short sentence that can make the mind peaceful. The aim of the research was to evaluate the differences effect of autogenic relaxation therapy to decrease pain level on postoperative patients Sectio Caesarea in Buha Hati Ciputat hospital. Method: Research design used was Quasy Experimental research with The Randomized Pretest-Posttest With Control Group Design involving 50 postoperative Sectio Caesarea patients consists of 25 respondents as intervention group and 25 respondents as control group. Sampling technique used Was Non Probability Sampling namely Purposive sampling techniques. Result: Average of pain levels at intervention group after had given autogenic relaxation therapy is 2,88 and at control group is 3,48. Result of Mann Whitney $U$ test, showed $p$-value $0,024<\alpha 0,05$. Conclusion: Differences pain levels at post operative patient Sectio Caesarea after had given autogenic relaxation therapy between intervention group and control group showed that there is differences effect of giving autogenic relaxation therapy to decrease pain levels at post operative patient Sectio Caesarea in Buah Hati Ciputat hospital.
\end{abstract}

Keywords $\quad$ : Autogenic Relaxation Therapy, Pain Levels 


\section{Latar Belakang}

Menurut WHO dalam penelitian Cut Sriyanti (2016), standar rata-rata sectio caesaria di sebuah negara sekitar 5-15\% per 1000 kelahiran didunia. Namun, dalam dekade 20 tahun terakhir ini Indonesia mengalami kenaikan proporsi sectio caesaria dari $5 \%$ menjadi $20 \%$. Secara umum jumlah persalinan sectio caesaria di rumah sakit pemerintah adalah sekitar $11 \%$ dari total persalinan, sedangkan rumah sakit swasta bisa sangat tinggi, yaitu lebih dari $30 \%$ dari total persalinan.

Berdasarkan Riskesdas tahun 2013 menunjukkan kelahiran sectio caesaria di Indonesia sebesar 9,8\%. Dalam data Riskesdas juga menunjukkan jumlah persalinan dengan sectio caesaria pada tahun 2013 di Provinsi Banten yaitu sebanyak $12,1 \%$ dari seluruh persalinan. Dan data Riskesdas Provinsi Banten pada tahun 2013 menunjukkan Kota Tangerang Selatan sebagai proporsi tertinggi persalinan dengan sectio caesaria yaitu sebesar $21,9 \%$. Data dari rekam medis RS Buah Hati Ciputat mencatat jumlah pasien sectio caesaria pada tahun 2016 yaitu sebanyak 1.687 jiwa atau sekitar $63 \%$ dari seluruh jumlah persalinan.

Pasien post operasi sectio caesaria biasanya akan merasakan nyeri luka operasi setelah beberapa jam pasca operasi sejalan dengan mulai pulihnya efek anestesi dari tubuh ibu. Hal ini yang banyak dikeluhkan oleh ibu post operasi sectio caesaria. Nyeri merupakan kondisi berupa perasaan tidak menyenangkan, bersifat sangat subjektif karena perasaan nyeri berbeda pada setiap orang dalam hal skala atau tingkatannya, dan hanya orang tersebutlah yang dapat menjelaskan atau mengevaluasi rasa nyeri yang dialaminya (Hidayat, 2016).

Untuk meredakan nyeri, perawat perlu memberikan penatalaksanaan nyeri yang tepat terhadap setiap individu. Dan salah satu terapi teknik relaksasi dalam dan imajinasi terbimbing untuk meredakan nyeri adalah dengan pemberian terapi autogenic. Teknik relaksasi autogenic merupakan salah satu teknik relaksasi yang bersumber dari diri sendiri berupa kata-kata atau kalimat pendek ataupun pikiran yang bisa membuat pikiran tentram. Relaksasi autogenic dilakukan dengan membayangkan diri sendiri berada dalam keadaan damai dan tenang, berfokus pada pengaturan nafas dan detakan jantung (Farada, 2011).

Dari survey pendahuluan yang dilakukan peneliti dengan mewawancarai pasien post operasi sectio caesaria didapatkan hampir seluruh responden mengeluh mengalami nyeri di luka operasi dengan skala nyeri 4-6 (nyeri sedang). Keluhan nyeri terutama terasa saat efek anestesi sudah mulai hilang, antara 2 sampai 4 jam setelah operasi dan semakin lama keluhan nyeri semakin bertambah. Dari survey tersebut, didapatkan pula 4 dari 10 responden mengatakan untuk 
mengurangi nyeri, responden melakukan teknik relaksasi tarik nafas dalam sesuai yang diajarkan perawat pada saat edukasi sebelum pembedahan. Namun, 6 dari seluruh responden, memilih menahan nyeri dengan tidak melakukan pergerakan yang dapat menimbulkan nyeri bertambah. Berdasarkan latar belakang diatas, peneliti tertarik untuk meneliti dengan judul perbedaan pengaruh pemberian terapi relaksasi autogenic terhadap penurunan tingkat nyeri pada pasien post operasi sectio caesaria di Rumah Sakit Buah Hati Ciputat.

\section{Metode}

Desain penelitian penelitian ini adalah Quasy Eksperimental dengan pendekatan The Randomized Pretest-Posttest With Control Group Design. Metode ini diganakan untuk membandingkan hasil intervensi dua kelompok yaitu kelompok kontrol dan kelompok intervensi yang keduanya diukur sebelum dan sesudah dilakukan intervensi terapi relaksasi autogenic (Yusuf, 2014).

Populasi dalam penelitian ini adalah ibu post operasi sectio caesaria di Rumah Sakit Buah Hati Ciputat. Dengan jumlah sampel yang digunakan sebanyak 50 responden, yang terdiri dari 25 responden kelompok intervensi dan 25 responden kelompok kontrol. Jumlah sampel didapatkan dengan perhitungan menggunakan rumus besaran sampel analitis numeric tidak berpasangan
(Dahlan, 2013). Teknik pengambilan sampel menggunakan Non probability sampling berupa teknik purposive sampling.

Cara pengumpulan data dalam penelitian ini dimulai dengan peneliti memberikan penjelasan kepada responden tentang terapi relaksasi autogenic mencakup cara, manfaat dan waktu pelaksanaan. Responden yang bersedia ikut dalam penelitian, peneliti akan meminta kesediaan responden untuk menandatangani lembar persetujuan dalam bentuk informant consent. Peneliti melakukan penelitian dalam dua tahap sekaligus yaitu tahap pertama dilakukan pada kelompok intervensi dan tahap kedua pada kelompok kontrol. Sebelum pemberian terapi, peneliti melakukan identifikasi tingkat nyeri responden. Penilaian nyeri menggunakan NRS (Numerical Rating Scale) dengan pedoman wawancara dan pencatatan dilembar observasi nyeri. Terapi relaksasi autogenic dilakukan antara pukul 07.00 WIB sampai pukul 17.00 setiap harinya selama 3 hari. Hari pertama terapi dilakukan 4-6 jam post operasi sectio caesaria, hari kedua dilakukan 24 jam post operasi sectio caesaria dan hari ketiga 24 jam dari hari kedua. Lakukan identifikasi ulang pada tingkat nyeri sesudah terapi dengan penilaian nyeri NRS. Pada kelompok kontrol, tidak mendapat perlakuan pemberian terapi relaksasi autogenic, responden hanya mengikuti program asuhan keperawatan yang berlaku 
di rumah sakit tempat penelitian berlangsung. Pada kelompok kontrol diobservasi dan dicatat tingkat nyeri pada waktu yang sama dengan kelompok intervensi.

\section{Hasil}

1. Tabel 1.1 Distribusi Frekuensi Kategori Tingkat Nyeri Sebelum Terapi Relaksasi Autogenic Kelompok Intervensi di Rumah Sakit Buah Hati Ciputat

\begin{tabular}{lcc}
\hline \multicolumn{1}{c}{ Tingkat nyeri } & Frekuensi & \% \\
\hline $\begin{array}{l}\text { Nyeri berat terkontrol } \\
\text { (skala nyeri 7-9) }\end{array}$ & 17 & 68 \\
\hline $\begin{array}{l}\text { Nyeri sedang (skala } \\
\text { nyeri 4-6) }\end{array}$ & 8 & 32 \\
\hline Total & 25 & 100 \\
\hline
\end{tabular}

Tabel 1.2 Distribusi Frekuensi Berdasarkan Kategori Tingkat Nyeri Sebelum Terapi Relaksasi Autogenic Kelompok Kontrol di Rumah Sakit Buah Hati Ciputat

\begin{tabular}{lcc}
\hline \multicolumn{1}{c}{ Tingkat nyeri } & Frekuensi & $\%$ \\
\hline $\begin{array}{l}\text { Nyeri berat terkontrol } \\
\text { (skala nyeri 7-9) }\end{array}$ & 17 & 68 \\
\hline $\begin{array}{l}\text { Nyeri sedang (skala nyeri } \\
\text { 4-6) }\end{array}$ & 8 & 32 \\
\hline Total & 25 & 100 \\
\hline
\end{tabular}

2. Tabel $2.1 \quad$ Distribusi Frekuensi Berdasarkan Kategori Tingkat Nyeri Sesudah Terapi Relaksasi Autogenic Kelompok Intervensi

\begin{tabular}{lcc}
\hline \multicolumn{1}{c}{ Tingkat nyeri } & Frekuensi & \% \\
\hline $\begin{array}{l}\text { Nyeri sedang (skala nyeri } \\
\text { 4-6) }\end{array}$ & 5 & 20 \\
\hline $\begin{array}{l}\text { Nyeri ringan (skala nyeri } \\
1-3)\end{array}$ & 20 & 80 \\
\hline Total & 25 & 100 \\
\hline
\end{tabular}

Tabel 2.2 Distribusi Frekuensi Berdasarkan Kategori Tingkat Nyeri Sesudah Terapi Relaksasi Autogenic Kelompok Kontrol

\begin{tabular}{lcc}
\hline \multicolumn{1}{c}{ Tingkat nyeri } & Frekuensi & \% \\
\hline $\begin{array}{l}\text { Nyeri sedang (skala nyeri } \\
\text { 4-6) }\end{array}$ & 11 & 44 \\
\hline $\begin{array}{l}\text { Nyeri ringan (skala nyeri } \\
1-3)\end{array}$ & 14 & 56 \\
\hline Total & 25 & 100 \\
\hline
\end{tabular}

3. Tabel 3.1 Perbedaan Tingkat Nyeri Sebelum Dan Sesudah Pemberian Terapi Relaksasi Autogenic Pada Kelompok Intervensi

\begin{tabular}{cccc}
\hline Tingkat Nyeri & Mean & SD & p-value \\
\hline \hline Tingkat nyeri & 7,16 & 1,281 & 0,000 \\
sebelum terapi & & & \\
relaksasi & & & \\
autogenic & & & \\
\cline { 1 - 3 } Tingkat nyeri & 2,84 & 1,179 & \\
sesudah terapi & $(1-6)$ & & \\
relaksasi & & & \\
autogenic & & & \\
\hline
\end{tabular}

Tabel 3.2 Perbedaan Tingkat Nyeri Sebelum Dan Sesudah Pemberian Terapi Relaksasi Autogenic Pada Kelompok Kontrol

\begin{tabular}{cccc}
\hline Tingkat Nyeri & Mean & SD & p-value \\
\hline Tingkat nyeri & 6,76 & 1,393 & 0,000 \\
sebelum terapi & & & \\
relaksasi & & & \\
autogenic & & & \\
\cline { 1 - 2 } Tingkat nyeri & 3,48 & 0,872 & \\
sesudah terapi & & & \\
relaksasi & & & \\
autogenic & & & \\
& &
\end{tabular}


4. Tabel 4.1 Perbedaan Tingkat Nyeri Pasien Post Operasi Sectio Caesaria Sebelum Terapi Relaksasi Autogenic Pada Kelompok Intervensi dan Kelompok Kontrol

\begin{tabular}{ccccc} 
Variabel & Kelompok & Mean & SD & $\begin{array}{c}\boldsymbol{p} \text { - } \\
\text { value }\end{array}$ \\
\hline \hline $\begin{array}{c}\text { Tingkat } \\
\text { nyeri }\end{array}$ & Intervensi & 7,16 & 1,281 & 0,369 \\
\cline { 2 - 4 } & Kontrol & 6,76 & 1,393 & \\
\hline
\end{tabular}

Tabel 4.2 Perbedaan Tingkat Nyeri Pasien Post Operasi Sectio Caesaria Sesudah Terapi Relaksasi Autogenic Pada Kelompok Intervensi dan Kelompok Kontrol

\begin{tabular}{ccccc} 
Variabel & Kelompok & Mean & SD & p-value \\
\hline \hline \multirow{2}{*}{$\begin{array}{c}\text { Tingkat } \\
\text { nyeri }\end{array}$} & Intervensi & 2,88 & 1,236 & 0,024 \\
\cline { 2 - 4 } & Kontrol & 3,48 & 0,872 & \\
\hline
\end{tabular}

Berdasarkan tabel 5.6, didapatkan data bahwa rata-rata tingkat nyeri pasien post operasi sectio caesaria sesudah diberikan terapi relaksasi autogenic pada kelompok intervensi sebesar 2,88 ( $\mathrm{SD}=1,236)$, sedangkan pada kelompok kontrol sebesar 3,48 $(\mathrm{SD}=0,872)$. Berdasarkan uji Mann-Whitney, didapatkan bahwa terdapat perbedaan tingkat nyeri pasien post operasi sectio caesaria sesudah terapi relaksasi autogenic pada kelompok intervensi dan kelompok kontrol, dengan nilai $p$ value $0,024<\alpha(0,05)$.

\section{Pembahasan}

Gambaran Tingkat Nyeri Sebelum Pemberian Terapi Relaksasi Autogenic Pada Pasien Post Operasi Sectio Caesaria

\section{Di Rumah Sakit Buah Hati Ciputat}

Berdasarkan tingkat nyeri sebelum dilakukan terapi relaksasi autogenic pada kelompok intervensi, didapatkan responden yang mengalami nyeri sedang sebanyak 8 responden (32\%), nyeri berat terkontrol sebanyak 17 responden (68\%). Dan tingkat nyeri sebelum dilakukan terapi relaksasi autogenic pada kelompok kontrol, didapatkan responden yang mengalami nyeri sedang 8 responden (32\%), nyeri berat terkontrol sebanyak 17 responden (68\%).

Secara teori, (Heriana, 2014) nyeri secara umum dapat didefinisikan sebagai suatu rasa yang tidak nyaman, baik ringan maupun berat. Nyeri bersifat sangat individual dan tidak dapat diukur secara subjektif, serta hanya pasien yang dapat merasakan adanya nyeri. Terdapat beberapa stimulus nyeri (Hidayat, 2016) diantaranya adalah adanya trauma pada jaringan tubuh misalnya karena pembedahan akibat terjadinya kerusakan jaringan dan iritasi secara langsung pada reseptor.

Nyeri sesudah pembedahan dirasakan oleh sebagian responden. Menurut peneliti, hal ini juga dikarenakan efek bius yang sudah mulai hilang 4-6 jam post operasi. Nyeri berat terkontrol dirasakan oleh hampir seluruh responden, baik kelompok 
intervensi maupun kelompok kontrol. Sedangkan sebagian kecil responden mengalami nyeri sedang setelah pembedahan. Menurut peneliti, hal ini dapat terjadi karena masing-masing responden baik kelompok intervensi maupun kelompok kontrol sama-sama belum diberikan perlakuan, selain edukasi terapi nafas dalam yang menjadi standar operasional rumah sakit, sehingga didapatkan hasil yang menunjukkan sebagian besar responden mengalami nyeri berat terkontrol dan sebagian kecil mengalami nyeri sedang.

\section{Gambaran Tingkat Nyeri Sesudah} Pemberian Terapi Relaksasi Autogenic Pada Pasien Post Operasi Sectio Caesaria

\section{Di Rumah Sakit Buah Hati Ciputat}

Berdasarkan tingkat nyeri sesudah dilakukan terapi relaksasi autogenic pada kelompok intervensi didapatkan, responden yang mengalami nyeri sedang sebanyak 5 responden (20\%) dan nyeri ringan sebanyak 20 responden $(80 \%)$. Dan tingkat nyeri pada kelompok kontrol didapatkan, responden yang mengalami nyeri sedang sebanyak 11 responden (44\%) dan nyeri ringan sebanyak 14 responden $(56 \%)$.

Menurut teori (Oberg, 2009 dalam Tiana, 2014), teknik relaksasi autogenic adalah salah satu teknik relaksasi yang bersumber dari diri sendiri berupa kata-kata atau kalimat pendek ataupun pikiran yang bisa membuat pikiran tentram. Relaksasi autogenic dilakukan dengan membayangkan diri sendiri berada dalam keadaan damai dan tenang, berfokus pada nafas dan tekanan jantung. Relaksasi autogenic akan membantu tubuh untuk membawa perintah melalui autosugesti untuk rileks sehingga dapat mengendalikan pernapasan, tekanan darah, denyut jantung serta suhu tubuh. Tubuh merasakan kehangatan, merupakan akibat dari arteri perifer yang mengalami vasodilatasi sedangkan ketegangan otot tubuh yang menurun mengakibatkan munculnya sensasi ringan. Perubahan- perubahan yang terjadi selama maupun setelah relaksasi mempengaruhi kerja saraf otonom. Ketegangan otot tubuh yang menurun melancarkan peredaran darah serta dapat mendistraksi nyeri yang dirasakan. Maka dinyatakan ada hubungan yang signifikan antara terapi relaksasi autogenic dengan penurunan tingkat nyeri.

Menurut peneliti, setelah diberikan perlakuan terapi relaksasi autogenic sebanyak 3 kali dengan durasi 15-20 menit selama 3 hari berturut-turut, didapatkan hasil bahwa ada penurunan tingkat nyeri. Dimana terapi relaksasi autogenic memberikan efek distraksi sekaligus relaksasi dengan mengalihkan fokus responden pada nyeri yang dirasakan dan dengan membayangkan diri sendiri dalam keadaan damai dan tenang, sehingga 
muncul sensasi ringan dan kenyamanan setelah terapi dilakukan, sehingga dapat menurunkan tingkat nyeri yang dirasakan.

\section{Perbedaan Pengaruh Pemberian Terapi}

Relaksasi Autogenic Terhadap

Penurunan Tingkat Nyeri Pada Pasien

Post Operasi Sectio Caesaria Di Rumah

Sakit Buah Hati Ciputat

Berdasarkan hasil penelitian yang menunjukkan Perbedaan Pengaruh

Pemberian Terapi Relaksasi Autogenic Terhadap Penurunan Tingkat Nyeri didapatkan hasil: rata-rata tingkat nyeri pada kelompok intervensi sesudah diberikan terapi relaksasi autogenic yaitu 2,88 dan pada kelompok kontrol yaitu 3,48. Data ini menunjukkan bahwa rata-rata tingkat nyeri pada kelompok intervensi lebih rendah daripada rata-rata skala nyeri pada kelompok kontrol sesudah diberikan terapi relaksasi autogenic. Hasil uji MannWhitney $U$, didapatkan $p$-value $0,024<\alpha$ $(0,05)$, hal ini menunjukkan bahwa ada perbedaan yang signifikan tingkat nyeri pasien post operasi sectio caesaria sesudah diberikan terapi relaksasi autogenic. Dan hal ini menunjukkan bahwa terdapat perbedaan pengaruh pemberian terapi relaksasi autogenic terhadap penurunan tingkat nyeri pada pasien post operasi sectio caesaria di Rumah Sakit Buah Hati Ciputat.

Dalam penelitian sebelumnya yang dilakukan oleh Dina Fithriana, 2016 menyatakan bahwa relaksasi autogenic merupakan teknik relaksasi yang dapat membantu mengurangi nyeri yang dilakukan oleh seseorang. Dengan teknik relaksasi autogenic pasien dapat melakukan teknik relaksasi melalui teknik sugesti diri (auto suggestive), dengan melakukan sendiri perubahan dalam dirinya sendiri, juga dapat mengatur pemunculan emosinya.

Menurut peneliti, hal ini menunjukkan bahwa teknik relaksasi autogenic dapat memberikan efek distraksi dengan mengalihkan fokus responden pada nyeri yang dirasakan dengan mengikuti langkahlangkah relaksasi dan efek rileksasi dengan membayangkan diri sendiri dalam keadaan damai dan tenang, sehingga muncul sensasi kenyamanan setelah terapi dilakukan, dan berpengaruh pada keadaan nyeri dengan menurunkan tingkat nyeri yang dirasakan pasien post operasi sectio caesaria.

\section{Kesimpulan}

Berdasarkan hasil penelitian maka dapat disimpulkan bahwa:

1. Tingkat nyeri sebelum pemberian terapi relaksasi autogenic pada pasien post operasi Sectio Caesaria di Rumah Sakit Buah Hati Ciputat didapatkan hasil: sebagian besar responden mengalami nyeri berat terkontrol yaitu sebanyak $68 \%$ responden baik pada kelompok intervensi maupun kelompok kontrol. Sedangkan nyeri sedang dirasakan 
sebanyak $32 \%$ responden pada kelompok intervensi dan kelompok kontrol.

2. Tingkat nyeri sesudah diberikan terapi relaksasi autogenic pada pasien post operasi Sectio Caesaria di Rumah Sakit Buah Hati Ciputat didapatkan hasil: sebagian besar responden mengalami nyeri ringan yaitu sebanyak $80 \%$ responden pada kelompok intervensi dan 56\% responden pada kelompok kontrol. Sedangkan nyeri sedang dirasakan sebanyak $20 \%$ responden pada kelompok intervensi dan $44 \%$ responden pada kelompok kontrol.

3. Terdapat perbedaan pengaruh pemberian terapi relaksasi autogenic terhadap penurunan tingkat nyeri nyeri pada pasien post operasi sectio caesaria di Rumah Sakit Buah Hati Ciputat, dengan nilai p-value 0,024 .

\section{DAFTAR PUSTAKA}

Dahlan, M. Sopiyudin. 2013. Besar Sampel Dan Cara Pengambilan Sampel Dalam Penelitian Kedokteran Dan Kesehatan. Jakarta: Salemba Medika

Farada, Rizka Amalia. 2011. Pengaruh Teknik Relaksasi Autogenik Terhadap Tingkat Kecemasan Pada Ibu Primigravida Trimester III Di Wilayah Kerja Puskesmas Kotakulon Kabupaten Bondowoso. Universitas Jember

Fithriana, Dina. Eva Marvia. Ageng Abdi Putra. 2016. Perbandingan Pemberian Terapi Relaksasi Autogenic Dan Aroma Terapi Terhadap Penurunan Tingkat Nyeri Haid (Dismenore) Pada Siswi Di MTs NW Samawa Sumbawa Besar. Jurnal Prima Vol. 2 no. 2 OktoberDesember 2016: 1-10
Heriana, Pelapina. 2014. Buku Ajar Kebutuhan Dasar Manusia. Tangerang Selatan: Binarupa Aksara Publisher

Hidayat, A. Aziz Alimul. Musrifatul Uliyah. 2016. Buku Ajar Keperawatan Dasar. Jakarta: Salemba Medika

Riset Kesehatan Dasar. 2013. Riskesdas 2013 Badan Penelitian dan Pengembangan Kesehatan Kementrian Kesehatan RI diunduh dari www.litbang.depkes.go.id pada tanggal 23 Maret 2017

Riskesdas. 2013. Buku 2 Riskesdas Dalam Angka Provinsi Banten 2013 diperoleh dari 150-99Z_Manuscript-361-1-1020150513.pdf diunduh dari www.litbang.depkes.go.id pada tanggal 23 Maret 2017

Sriyanti, Cut. 2016. Pengaruh Mobilisasi Dini Terhadap Proses Penyembuhan Luka Post SC Di Rumah Sakit Umum Daerah Dr. Zainoel Abidin Banda Aceh. Jurnal Pionir Volume 3 Nomor 2 Januari- Juni 2016: 85-90

Tiana, Yulis. 2014. Pengaruh Intervensi Keperawatan Teknik Relaksasi Autogenik Terhadap Penurunan Tingkat Kecemasan Pada Pasien Pre Operasi Di RSUD Ungaran. Universitas Ngudi Waluyo Ungaran

Yusuf, Muri. 2014. Metode Penelitian: Kuantitatif, Kualitatif Dan Penelitian Gabungan. Jakarta: Kencana Prenadamedia Group 